\title{
The effect of an auxin (IBA), fungicide (Captan) and of wounding on the rooting of softwood apple (Malus Mill.) cuttings
}

\author{
RYSZARD S. GORECKI
}

\author{
Plant Physiology Department, Academy of Agriculture in Poznań*
}

(Received: November 23, 1978.)

\begin{abstract}
Softwood cuttings of rootstocks M 26, M 104 and M 106 were investigated under ordinary propagating greenhouse conditions without basal heat or mist. Rooting was stimulated most effectively by indole-3-butyric acid (IBA) at a concentration of $0,5 \%$ in a mixture of talc with a commercial powdered fungicide, Captan $(6: 4 \mathrm{wt} / \mathrm{wt})$. Wounding of the basal part of cuttings increased the percentage of rooting and increased the number of roots per cutting and the length of the root system. Captan restricted decay of cuttings, promoted rooting, probably indirectly, and improved the root-system quality. The best results obtained were $91 \%, 68 \%$ and $100 \%$ rooted cuttings for the clones M 26, M 104 and M 106, respectively. The time of cuttings collection (July - September) had no significant effect on their rooting.
\end{abstract}

\section{INTRODUCTION}

Stool layering is an expensive and not efficient method of apple rootstock propagation. Therefore, propagation trials using softwood cuttings (e.g., Pi ą tkowski et al. 1973), hardwood cuttings (H ow ard 1977) or tissue culture ( $\mathrm{J}$ o n e s 1977 ) have been performed. The method chosen depended upon the season and technical facilities available.

Root formation in cuttings depends upon many factors such as the time of collection, composition of rooting medium and its $\mathrm{pH}$, temperatures of air and the medium, humidity and light conditions ( $\mathrm{H}$ a r t m a n $\mathrm{n}$ and Kester 1959). Among substances promoting rooting, auxins are mainly used to induce adventitious roots in softwood cuttings of apple (Danilov 1967; Czynczyk and Grzyb 1971; Piątkowski et al. 1973).

Wouding the base of the cuttings can markedly promote root production in some species which are normally rather difficult to root for-

* Present address: Res. Inst. Veg. Crops, Biol. Dept., 96-100 Skierniewice P.O. Box 69, Poland. 
mation, but not all species respond equally to this treatment ( $\mathrm{H} \mathrm{art-}$ $\mathrm{mann}$ and Kester 1959).

Decay sometimes causes losses of large numbers of cuttings. There have been trials to control decay by fungicide application (Thielges and Hoitnik 1972, Piątkowski et al. 1973).

The purpose of this work was to determine the rooting ability of M 26, M 104 and M 106 apple softwood cuttings as affected by an exogenous auxin, indole-3-butyric acid (IBA), Captan fungicide and wounding in propagating greenhouse conditions without basal heating or intermittent mist.

\section{MATERIALS AND METHODS}

The shoots for cuttings were gathered from a nursery in Kociałkowa Górka and transported promptly to Kórnik Arboretum near Poznan where they were immediately cut into cuttings. The cuttings were prepared from the apical part of the shoots, with their tips cut off. Each cutting consisted of 4 leaves, with lowest leaf excised and the remaining shortened to about one-half of their length.

Wounding was done by removing a slice of bark at the base of cutting from the side opposite to the basal bud (Fig. 1). Bases of cuttings wereimmersed into the talc powder preparation of the given substance or they were first dipped in an alcohol solution of auxin and later into talc with Captan.

The rooting medium was composed of a $15 \mathrm{~cm}$ layer of peat moss covered with $5 \mathrm{~cm}$ of washed, coarse sand without bottom heating. The cuttings were inserted into the rooting medium as shallowly as possible $(0.5-1.0 \mathrm{~cm})$. Mean daily air temperatures in the greenhouse ranged from 20 to $27^{\circ} \mathrm{C}$ and the r.h. from 81 to 83 per cent. The cuttings were

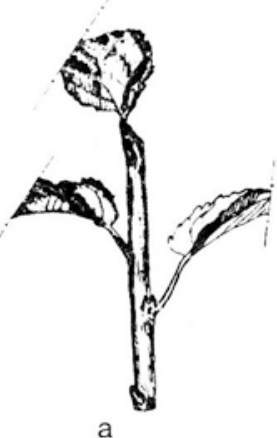

a

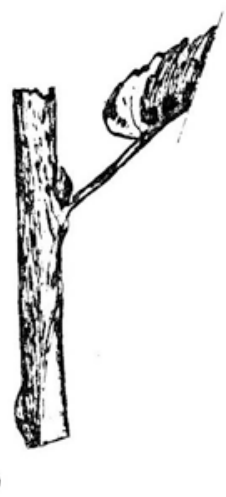

Fig. 1. Unwounded cutting (a) - base of wounded apple softwood cutting (b) 


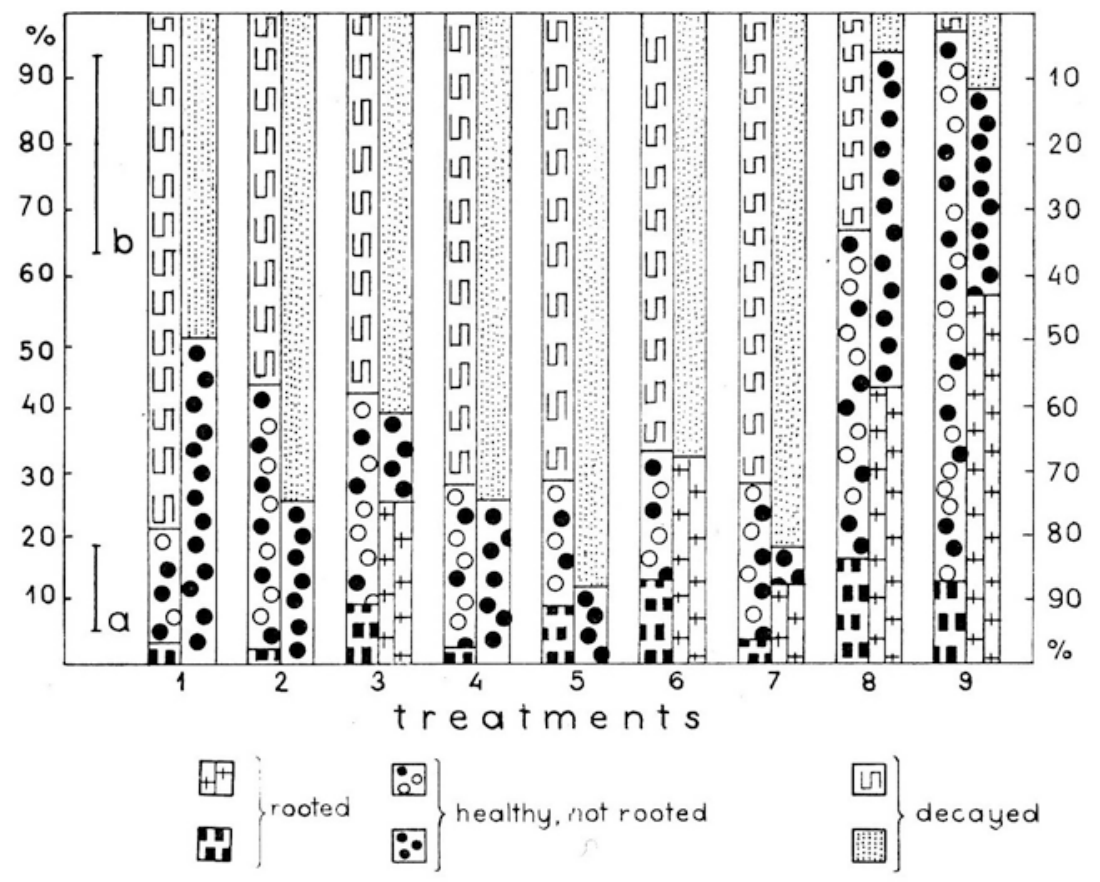

Fig. 2. The effect of IBA, Captan and wounding on rooting and decaying of M 26 softwood cuttings (experiment 1)

Treatments: $1-$ check (talc), $2-0,1 \%$ IBA in talc, $3-0,25 \%$ IBA in talc, $4-0,5 \%$ IBA in talc, $5-0,1 \%$ IBA in solution ( $\sin$ ), quick-dip (QD), $6-0,25 \%$ IBA in $\sin , \mathrm{QD}, 7-0,5 \%$ IBA in $\sin$, QD, $8-0,1 \%$ IBA in $100 \%$ Captan, $9-100 \%$ Captan.

Bars indicate significant differences between treatments at $95 \%$ probability level: $a$ - for rooting, $b$ - for decaying

In each treatments: left bar present unwounded cuttings and right bar - wounded cuttings

collected on August 8th and September 2nd in 1971 (expt 1,2) and on July 6th and August 24th in 1972 (expt 3, 4).

The number of rooted and decayed cuttings were determined after 49 days of rooting. There were 4 to 6 replications with 8 to 18 cuttings in one treatment. The results were analysed statistically with the analyssis of variance using Duncan's multiple range test for differences at $\mathrm{P}=0.05$.

\section{RESULTS}

Wouding combined with the application of IBA caused better rooting of cuttings of the clones studied (Fig. 2, 3 and 4), increasing the number of roots per cutting as well as the total length of roots (Table 1). In the case of the optimal IBA concentration, wounding caused still better rooting (Fig. 2, 3 and 4) but sometimes the number of decayed cuttings 


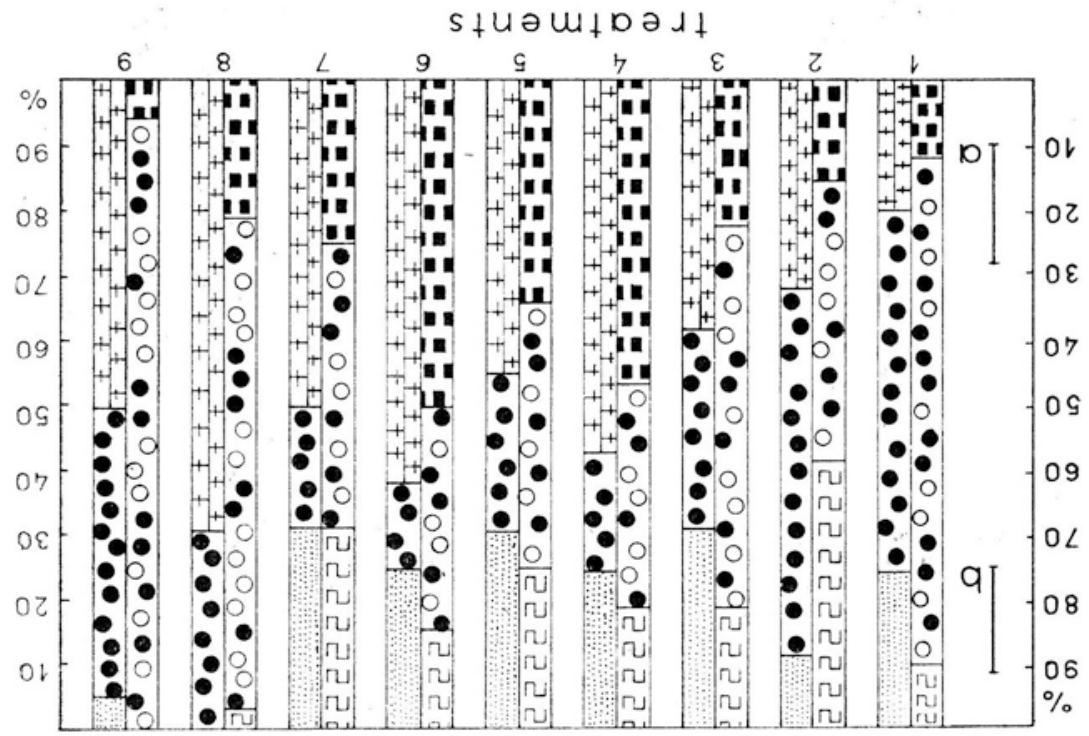

Fig. 3. The effect of IBA, Captan and wounding on rooting and decaying of M 104 softwood cuttings (experiment 1)

Denominations and explanations as for Fig. 2

also increased if Captan was not applied (Fig. 2, 3). Wouding increased the number of roots on the cuttings of all clones by an average of 46 per cent and also increased the length of roots by 45 per cent (Table 1). The best treatments for wounded cuttings were consistantly better than for unwounded ones (Table 2). The cuttings from the treatments which resulted in a higher per cent of rooting also developed more abundant root systems.

Captan promoted better rooting of cuttings and also reduced the number of decayed cuttings (Fig. 2, 3). It was of importance particularly in the case of more susceptible clone M 26. The cuttings treated with Captan showed no signs of Captan phytotoxicity also when IBA was used and wounds were made (Fig. 4). Captan did not show any negative effect on the quality of the root system, rather the cuttings treated with it rooted better, had 47 per cent less decay, produced more roots by 36 per cent and longer root systems by 73 per cent tham the cuttings not treated with this fungicide (Table 3 ).

The best rooting preparation was that with IBA $(0.5 \%)$ in a powder composed of 60 per cent talc and 40 per cent Captan. IBA administered by the quick-dip method was sometimes better than powdered preparations, but results obtained were rather erratic and inconsistant.

There were no statistical differences between the results obtained with 


\section{Table 1}

The effect of IBA treatment and wounding of cuttings on the number of roots per rooted cutting and the length of root systems (experiment 2). The data were not evaluated statistically

\begin{tabular}{|c|c|c|c|c|c|}
\hline \multirow[b]{2}{*}{ Clone } & \multirow[b]{2}{*}{$\begin{array}{l}\text { Treat- } \\
\text { ment* }\end{array}$} & \multicolumn{2}{|c|}{ Unwounded cuttings } & \multicolumn{2}{|c|}{ Wounded cuttings } \\
\hline & & $\begin{array}{l}\text { No. of roots } \\
\text { per cutting }\end{array}$ & $\begin{array}{c}\text { root length } \\
\text { per cutting } \\
(\mathrm{mm})\end{array}$ & $\begin{array}{l}\text { No. of roots } \\
\text { per cutting }\end{array}$ & $\begin{array}{c}\text { root length } \\
\text { per cutting } \\
(\mathrm{mm})\end{array}$ \\
\hline \multirow{7}{*}{ M 26} & 1 & 1 & 35 & 1.7 & 47 \\
\hline & 2 & 0 & 0 & 1.0 & 20 \\
\hline & 3 & 0 & 0 & 1.6 & 83 \\
\hline & 4 & 3.7 & 99 & 3.8 & 140 \\
\hline & 5 & 6.3 & 107 & 7.5 & 213 \\
\hline & 6 & 2.3 & 52 & $2 . \overline{5}$ & 87 \\
\hline & 7 & 3.3 & 54 & 3.5 & 83 \\
\hline Mean & & 2.4 & 49.6 & 3.1 & 96.1 \\
\hline \multirow{7}{*}{ M 106} & 1 & 0 & 0 & 1 & 40 \\
\hline & 2 & 1 & 0 & 1 & 50 \\
\hline & 3 & 1 & 42 & 0 & 0 \\
\hline & 4 & 6.1 & 270 & 8.2 & 319 \\
\hline & 5 & 7 & 257 & 9.3 & 339 \\
\hline & 6 & 4.3 & 277 & 3.6 & 197 \\
\hline & 7 & 4.2 & 167 & 5.5 & 271 \\
\hline Mean & & 3.2 & 144.7 & 5.3 & 172.3 \\
\hline \multirow{7}{*}{ M 104} & 1 & 0 & 0 & 1.7 & 40 \\
\hline & 2 & 1 & 10 & 2.2 & 65 \\
\hline & 3 & 1 & 10 & 1.5 & 45 \\
\hline & 4 & 3.6 & 76 & 6.6 & 198 \\
\hline & 5 & 6.4 & 111 & 6.5 & 173 \\
\hline & 6 & 3 & 93 & 4.0 & 118 \\
\hline & 7 & 4 & 140 & 4.3 & 98 \\
\hline Mean & & 2.7 & 62.9 & 3.8 & 105.3 \\
\hline
\end{tabular}

- For treatments see Fig. 4.

the same treatments in 1971 and 1972 in spite of different weather conditions.

The overall results indicate that the best rooting was obtained with M 106 cuttings, followed by M 104 and M 26.

\section{DISCUSSION}

The rooting in the experiments discussed was 49 days, because it was earlier found that this period of time is sufficient to assess the responses of cuttings to investigated factors. However, the results may change when 


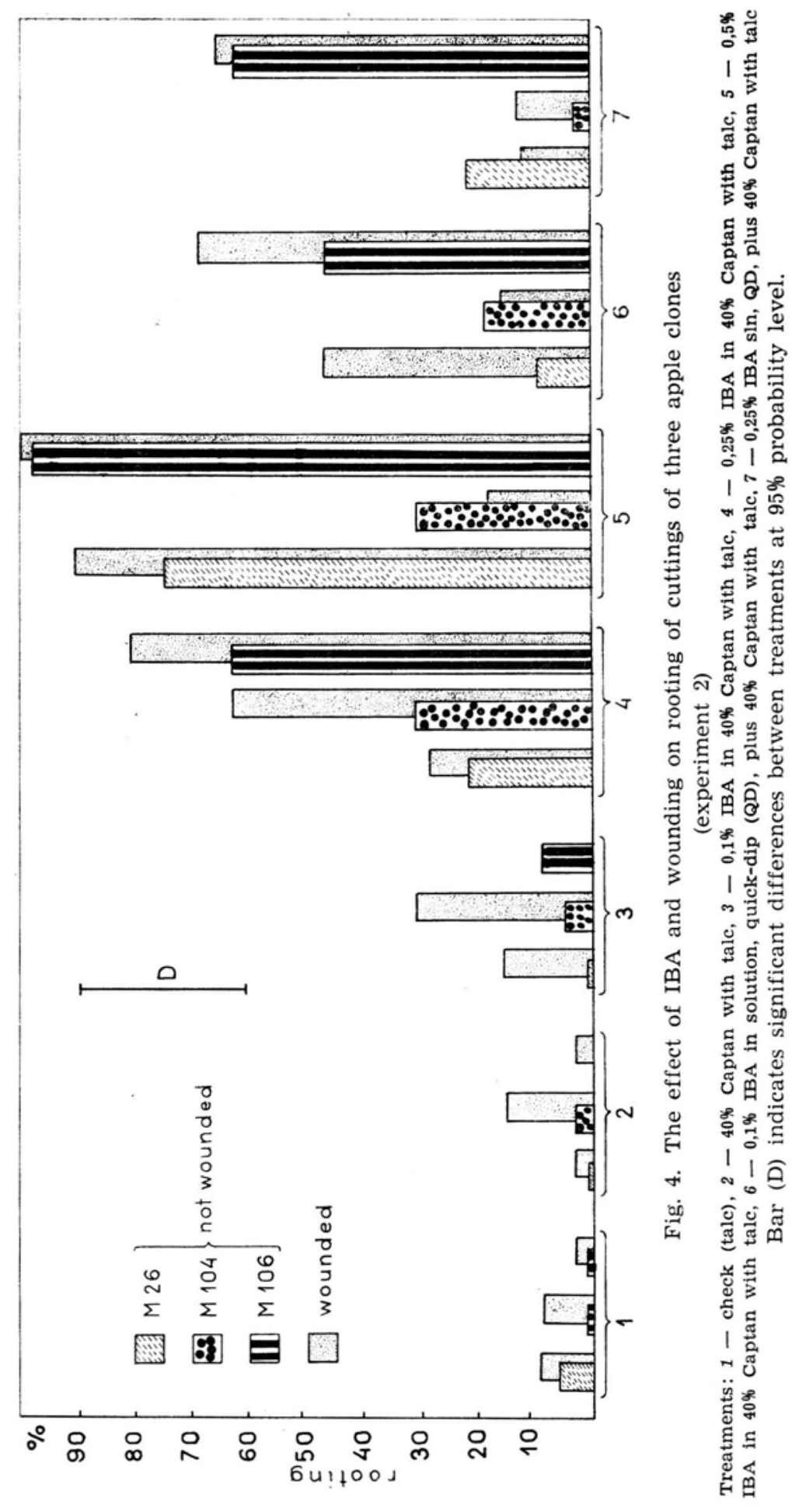


T a ble 2

Mean rooting in the controls and in the best treatments of wounded vs unwounded cuttings (\%)

\begin{tabular}{clrr}
\hline Clone & Treatment & $\begin{array}{c}\text { Wounded } \\
\text { cuttings }\end{array}$ & $\begin{array}{c}\text { Unwounded } \\
\text { cuttings }\end{array}$ \\
\hline \multirow{2}{*}{ M 26} & $\begin{array}{l}\text { control } \\
\text { the best }\end{array}$ & $\begin{array}{r}4.5(2) \\
73.5(2)\end{array}$ & $2.8(4)$ \\
& control & $20.0(2)$ & $11.0(4)$ \\
M 104 & the best & $65.5(2)$ & $36.8(4)$ \\
\hline \multirow{2}{*}{ M 106} & control & $3.0(1)$ & $1.3(3)$ \\
& the best & $100.0(1)$ & $70.7(3)$ \\
\hline
\end{tabular}

Number of experiments performed are indicated in parentheses.

Table 3

The effect of IBA and Captan on the rooting, decay and root-systems of three apple-clone cuttings. Data combined from experiments nos. 3 and 4

\begin{tabular}{|c|c|c|c|c|c|}
\hline Clone & $\begin{array}{l}\text { Treat- } \\
\text { ment * }\end{array}$ & Rooted $(\%)$ & Decayed $(\%)$ & $\begin{array}{l}\text { No. of roots } \\
\text { per rooted } \\
\text { cutting }\end{array}$ & $\begin{array}{l}\text { Root length } \\
\text { per rooted } \\
\text { cutting }(\mathrm{mm})\end{array}$ \\
\hline \multirow{4}{*}{ M 26} & 1 & $1 \mathrm{a}$ & $61 \mathrm{~d}$ & 0,5 & 3 \\
\hline & 2 & $1 \mathrm{a}$ & $50 \mathrm{c}$ & 2 & 53 \\
\hline & 3 & $1 \mathrm{a}$ & $84 \mathrm{~d}$ & 1,3 & 7 \\
\hline & 4 & $11 \mathrm{~b}$ & $44 \mathrm{c}$ & 2,9 & 133 \\
\hline \multirow{4}{*}{ M 104} & 1 & $5 \mathrm{a}$ & $50 \mathrm{c}$ & 2,1 & 51 \\
\hline & 2 & $14 \mathrm{~b}$ & $12 a b$ & 2,3 & 73 \\
\hline & 3 & $20 \mathrm{~b}$ & $19 \mathrm{~b}$ & 4,4 & 163 \\
\hline & 4 & $34 \mathrm{c}$ & 4 a & 6,2 & 218 \\
\hline \multirow{4}{*}{ M 106} & 1 & $1 \mathrm{a}$ & $19 \mathrm{~b}$ & 3,5 & 48 \\
\hline & 2 & $1 \mathrm{a}$ & $11 a b$ & 1,0 & 5 \\
\hline & 3 & $23 \mathrm{c}$ & $14 a b$ & 3,1 & 198 \\
\hline & 4 & $51 \mathrm{~d}$ & $9 \mathrm{a}$ & 5,9 & 334 \\
\hline
\end{tabular}

* Treatments: 1 - check (talc), $2-40 \%$ Captan with talc, $3-0.5 \%$ IBA in talc, $4-0.5 \%$ IBA in $40 \%$ Captan with talc. Data marked with the same letters do not differ within columns at $\mathrm{P}=95 \%$. The remaining data were not evaluated statistically.

the length of the rooting period is varied: compare rooting of the clone M 104 after 35 and 49 days (Fig. 5). After 49 days, the differences between the control and the remaining treatments decreased. This result indicates that, as long as cuttings remain heathly, three exists a chance of their rootings. Therefore, the protection of cuttings against rotting is an important task.

Some preliminary results of the author indicate that the decay of cuttings is accompanied by common fungi such as Botrytis cinerea Per- 


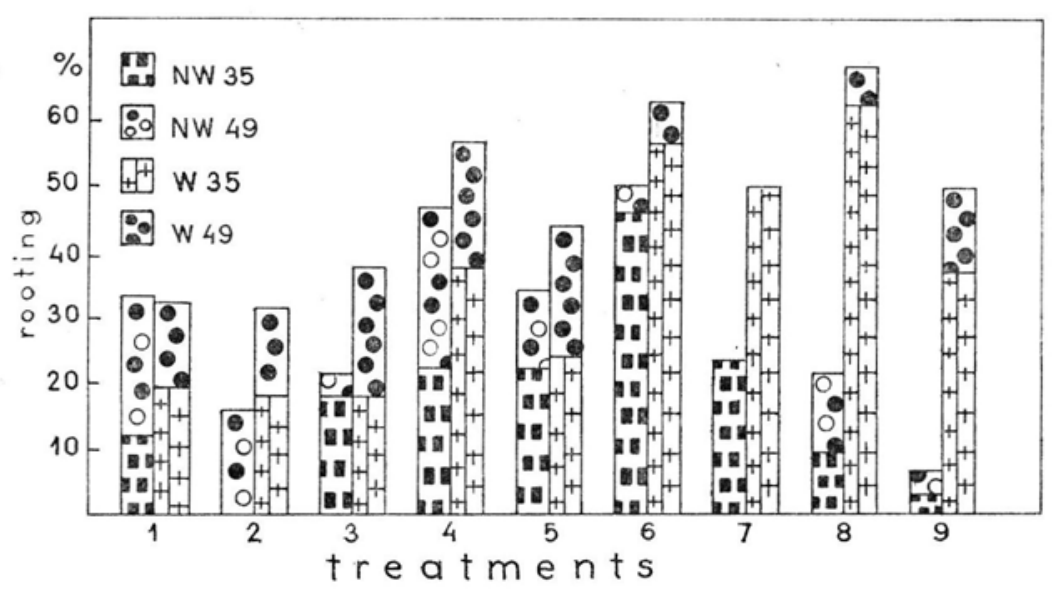

Fig. 5. Rooting of unwounded (NW) and wounded (W) cuttings of M 104 after 35 and 49 days

For details see Figs 2 and 3

soon, Fusarium solani App. and Woll., Alternaria tenuis Nees. and Trichoderma lignorum Tode. The application of growth regulators my increase the susceptibility of plants to diseases (van Andel 1968; Hor s fall and Dimond 1957), therefore, Captan may function as protective agent (M e r c a d o-Flores and Kester 1966; Thibault and $\mathrm{Hermann}$ 1971; Thielges and Hotinik 1972; Piątkowski et al. 1973). However, Guerriero and Loreti (1968) found that Captan did not act satisfactorily when applied to apple cuttings in a liquid form, but, on other hand, presoaking of Prunus sp. cuttings in benomyl solution gave good results (Fiorino et al. 1970; Hull an c a and $\mathrm{Cummins} 1974$ ).

As shown is this paper, Captan may improve rooting of apple cuttings. This was also found by Piątkowski et al. (1973) for gooseberry cuttings. It is possible that Captan can prevent or delay IBA bio-degradation and thus prolong its activity. It is also important that Captan may reduce the number of deteriorating cuttings and in such a way improve their chance for rooting. In the case of wounded cuttings a preventive function of the fungicide may be even more important because the area exposed to infection is then bigger.

It is well known that wounding promotes rooting in the cuttings of difficult-to-root species (Enright 1957; Hartmann and Kester 1959), however, very different results have been obtained in cases of hardwood cuttings of several fruit trees (T s chaikovskaya 1968; Howard 1968; Nicotra 1970, 1971; Young and Westwood 1975). In the presented experiments wounding of cuttings evoked better rooting. Normally, roots are initiated in deeper layers of tissues close to the cambium ( $\mathrm{Eriks}$ en 1971), therefore, it is possible that removal of 
some tissue from cutting shortens the distance to be passed by root primordia. In addition exogenous growth regulators can more easily penetrate the wounded cutting. The callus tissue on the wounded surfaces is very active and adventitious roots may sometimes be formed from it (We r e in $\mathrm{g}$ and Phillips 1976).

It was found that cuttings collected earlier, root better in conditions similiar to those reported herein ( $\mathrm{Pi}$ a t k ow ski et al. 1973). In the experiments discussed here the effect of the time of cuttings collection was not significant probably due to the fact than even earlier experiments (July, August) were too late in comparison with the suggested optimal time (June). Nevertheless, even in this late period cuttings rooted rather well.

Usually, better results were obtained with powdered IBA with Captan. The superiority of powdered preparations of growth substances over solutions was found also by Herm a n n (1968).

Czynczyk and Grzyb (1971) recorded 65 per cent rooting of MI 26 cuttings with $2500 \mathrm{ppm}$ IBA, basal heat and misting. R owe-Dutton (1962) rooted $100 \%$ of the IVI 104 cuttings with 2 per cent IBA powder but 84 per cent with the alcohol solution of IBA $(3 \mathrm{mg} / \mathrm{ml})$. Ninety-six per cent of the MI 106 clone rooted with the alcohol preparation. C z y n c z y k and Grzy b (1971) obtained 74 per cent rooting of M 106 cuttings with NAA (3000 ppm). Piątkowski et al. (1973) rooted $87 \%$ of the M 106 softwood cuttings with Seradix 2 or 3 . It may be concluded that optimal concentrations in the given examples were rather close to each other and agree with this author's results.

The physiological changes in cuttings during their rooting will be described in a forthcoming paper.

\section{REFERENCES}

A ndel van O. M., 1968. Shifts in disease resistance induced by growth regulators. Neth. J. Pl. Path., 74 (suppl.): 113-120.

Czynczyk A., Grzyb Z., 1971. Rozmnażanie podkładek dla drzew owocowych przez sadzonki zielne i zdrewniałe. Ogrodnictwo 4: 98-102.

Danilov A. J., 1967. We propagate apples from softwood cuttings. Sadovodstvo 5: 28-29 (in Russian).

Enright L. J., 1957. Vegetative propagation of Liriodendron tulipifera, J. For. $55,12$.

Eriksen E. N., 1971. Anatomiske og fysiologiske forhold ved roddannelse pá stiklinger. Saet. Uges. Agron., 116, 26-27: 574-577.

Fiorino P., Cummins J. N., Gilpatrick J., 1970. Increased production of Prunus besseyi Bailey softwood cuttings with preplanting soak in benomyl. Comb. Proc. Int. Plant Prop. Soc. 19: 320-329.

Guerriero R., Loreti F., 1968. Studies on the propagation by cuttings of clonal apple rootstocks with bottom heat. Riv. Ortoflorofrut. Ital. 52:757-758.

H a r tman n H. T., Kester D. E., 1959. Plant propagation principles and practices. Englewood Cliffs, N. J., Prentice-Hall Inc. 
Hermann L., 1968. Rooting of Bartlett's softwood cuttings. Comparative effects of two ways of auxin absorption. Ann. Amêlior. Plantes 18:447-454.

Horsfall J. G., Dimond A. E., 1957. Interactions of tissue sugar, growth substances and disease susceptibility. Zeitschr. Pflanzenkrankh. (Pflanzenpath.) und Pflanzensch. $64(7 / 10): 415-421$.

How ard B. H., 1968. The influence of butyric acid and basal temperature on the rooting of apple rootstocks hardwood cuttings. J. Hort. Sci. 44:303-310.

How a rd B. H., 1977. Propagation of deciduous trees by cuttings. I. Leafless hardwood cuttings. ARC Res. Rev. 2, 3:71-74.

Hulla n c a H., Cummins J. N., 1974. Rooting capacities of some Prunus fruticosa $\times P$. avium hybrids. HortScience $9,2: 123-124$.

J o nes O. P., 1977. Propagation of deciduous trees by cuttings. II. Propagation in vitro. ARC Res. Rev. 2, 3:74-75.

Mercado-Flores I., Kester D. E., 1966. Factors affecting the propagation of some interspecyfic hybrids of almond by cuttings. Proc. Amer. Soc. Hort. Sci. 86: $225-231$.

$\mathrm{N}$ i c otr a A., 1971. Prove di radicazione di talee ditalee legnose di albicocco, mediante la tecnica del riscaldamento basale. Ann. Ist. Sper. Fruct.-Roma I-N1: 137-146.

Nicotra A., 1971. Prove di radicazione di talee di, S. Giuliano A, fediante la tecnica del riscaldamento basale. Ann. Ist. Sper. Fruct.-Roma, II-N1: 395-400.

Piątkowski M. G., Jankiewicz L. S., Ka sprzyk S., 1973. Use of auxin, fungicides and rooting cofactors to induce root formation in softwood cuttings of apple, gooseberry and some ornamental plants. Acta agrobot. 26 (1): 191-201.

Rowe-Dutton P., 1962. Mist propagation of cuttings. Moscow, (in Russian).

Tschaikovskaya Z. P., 1968. Vegetative propagation of quince, Sadovodstvo, 1, 23 (in Russian).

Thibault B., Hermann L., 1971. Essais de bouturage ligneux de la variéte Williams (Pyrus communis L.). Ann, Amelior. Plantes, 21, 4:423-443.

Thielges B. A., Hoitnik H. A. J., 1972. Fungicides aid rooting of eastern white pine cuttings. For. Sci. 18 (1): 54-55.

W a reig P. F., Phillips I. D. J., 1976. Regulacja wzrostu i różnicowania u roślin. PWN, Warszawa.

Y oung M. J., W estwood M. N., 1975. Influence of wounding and chilling on rooting of pear cuttings. HortScience 10 (4) : 339-400.

Wpływ auksyny (IBA), fungicydu „Kaptan” i zranień na ukorzenianie się sadzonek zielnych jabłoni (Malus Mill.)

\section{Streszczenie}

Badano wpływ kwasu 3-indolilo masłowego (IBA), fungicydu Kaptan i nacinania podstaw sadzonek na ich ukorzenianie. Doświadczenia przeprowadzono z zielnymi podkładkami jabłoniowymi M 26, IM 104, i M $106 \mathrm{w}$ mnożarce bez ogrzewnego podłoża i bez zamgławiania. Najlepsze rezultaty otrzymano z preparatem proszkowym zawierającym 0,5\% IBA w proszku złożonym z talku i Kaptanu (6:4). Nacinanie sadzonek, oprócz znacznego zwiększenia procentu zakorzenienia, powodowalo zwiększenie liczby korzeni na sadzonkę oraz zwiększenie się długości systemu korzeniowego. Kaptan obniżał procent sadzonek gnijących oraz przyczynial się jednocześnie do znacznie lepszego zakorzeniania, polepszając także jakość systemu korzeniowego. Najlepsze wyniki ukorzeniania wynosiły $91 \%$ dla M 26, 68\% dla M 104 i $100 \%$ dla sadzonek M 106. Nie stwierdzono istotnego wplywu terminu pobierania sadzonek na uzyskane wyniki. 